\title{
New Normal at Islamic Boarding School During the Covid-19 Pandemic in Sumbawa Island
}

\author{
Satriya Pranata* \\ Faculty of Nursing and Health Sciences \\ Muhammadiyah University of \\ Semarang \\ Semarang, Indonesia \\ satriya.pranata@unimus.ac.id
}

\author{
Fadillah Ahmad Nur \\ Faculty of Islamic Studies \\ Muhammadiyah University of Malang \\ Indonesia \\ fadillahahmadnur33@gmail.com
}

\author{
Herlinda Wulandari \\ Faculty of Nursing and Health Sciences \\ Muhammadiyah University of \\ Semarang \\ Semarang, Indonesia \\ wulan.herlinda@gmail.com
}

\author{
Muhammad Johar Zainuddin \\ Abu Bakar Islamic Boarding School \\ Indonesia \\ Muhammad.johar@yahoo.com
}

\author{
Muhammad Hidayat \\ Dea Malela International Islamic \\ Boarding School \\ Indonesia \\ hidayatnurasikin71@gmail.com
}

\begin{abstract}
A number of Islamic boarding schools are growing rapidly. However, living in Islamic Boarding School give a high risk of Covid-19 transmission because of the intensive interraction of the students and teachers within the same isolated environment while doing activities together. There is no research report on the new normal of Islamic boarding schools during the Covid-19 pandemic in Sumbawa. The purpose of this study was to explore the new normal of lifestyle at Islamic boarding schools during the Covid-19 pandemic in Sumbawa. The descriptive research method was used in this research. Sumbawa was chosen to represent the new normal conditions carried out by Islamic boarding schools during the Covid-19 pandemic in West Nusa Tenggara. 9 Islamic boarding schools were chosen with 88 respondents who were given a questionnaire and interview. The researchers used a purposive sampling technique with univariate data analysis presented in a table describing the amount and percentage. There has been a change in activities, regulations when entering Islamic boarding schools and the need for health for each element in it due to the Covid-19 pandemic. The finding indicates that the number of teachers who had received counseling and training on Health protocols was $18(20.5 \%), 40(45.5 \%)$ were online with schools and $30(34.1 \%)$ had already been from other sources. $72(81.8 \%)$ agreed students should start studying at school. Then $16(18.2 \%)$ disagreed, $49(57 \%)$ have attended seminars about COVID and $37(43 \%)$ never. $37(42 \%)$ had attended training on COVID and $51(58 \%)$ had never attended the training. $55(62.1 \%)$ currently admitted that the students have studied at the school. $9(10.3 \%)$, and $24(27.6 \%)$ students are studying at school with dormitory. $69(78.4 \%)$ answered that the students had entered the school and $19(20.2 \%)$ answered that they had not. $43(48.9 \%)$ required students to carry out rapid tests, $7(8 \%)$ required PCR and, 29 $(33 \%)$ self-isolation at school. Summary: Majority of respondence hope that the students will start to learn face-toface by applying the right health protocol. Health workers are supposed to do a socialization in Islamic boarding schools about health protocol to prevent the transmission of Covid-19.
\end{abstract}

Keywords—new normal, islamic boarding school, covid-19, pandemic

\section{INTRODUCTION}

The number of Islamic boarding schools is growing rapidly. In 2020, about 28,194 Islamic boarding schools in Indonesia more than five million students, [1]. Currently, there are 664 Islamic Boarding schools in West Nusa Tenggara and 22 are located in Sumbawa district, [1].

The pandemic of Covid-19 have made life changes gradually, [2,3]. Before the pandemic, all the elements of society lived normally without any kinds of anixieties, uneasieness, and qualm towards this infectious disease [4]. The prevention of Covid-19 transmission has led most agencies to make new normal, [5-9], no exception in the Islamic boarding school environment. New normal has been carried out by several Islamic boarding schools in Indonesia which include actively practicing social distancing during studying or praying, reducing visitors from outside, or implementing an online learning in their respective homes. Despite the pandemic is still happening, there are several Islamic boarding schools that started to do an face-to-face learning by implementing the current health protocols.

Living in Islamic Boarding School gives a high risk of Covid-19 transmission because of the intensive interraction of the students and teachers within the same isolated environment while doing activities together. Furthermore, the number of visitors like parents, families, or relatives will escalate the risk of Covid-19 transmission. There is no guarantee that they are not infected by Covid-19. This due to not all people commit the current health protocols properly. An appropriate management to respond these conditions is desperately needed. The school authorities need to ensure that every elements can always be clean and healthy.

Regarding to the new normal implementation at Islamic boarding schools in Sumbawa island, researchers are interested in conducting studies and explored about lifestyle changes, learning processes and any difficulties that occur in the boarding school environment during a new normal situation. Brief interviews about teachers' expectations of Islamic boarding schools, government and health workers 
were also explored to enrich the information presented in this study.

Hopefully, with the discovery of data regarding the new normal of Islamic boarding schools and the expectations of teachers to boarding school officials, the government, health workers, and stakeholders can make decisions and policies for preventing Covid-19 transmission based on data, community needs and conditions in the Islamic boarding school.

\section{METHODS}

\section{A. Design}

This paper examined the new normal of lifestyle from Islamic boarding school by applying a descriptive normative survey method. The descriptive normative survey method is a type of research that seeks to describe an object, behavior and perspective in accordance with existing reality, [10]. Therefore, researchers and readers can understand a phenomenon that occurs in the setting used as the object of the study, $[10,11]$.

\section{B. Location}

Sumbawa Regency was chosen as the research location to represent the new normal on Islamic boarding schools during the Covid-19 pandemic in West Nusa Tenggara. The number of Islamic boarding schools studied were 9 Islamic boarding schools, namely Dea Malela International Islamic Boarding School, Abu Bakar, Al-Hikmah, NW Sumbawa, Aisyah, Gunung Galesa, Al-Mutmainnah, Maronge, and Al-Majdiah Islamic boarding School with 88 respondents who were given questionnaires and interviews by researchers.

\section{Techniques for determining informants and analysis}

The purposive sampling technique used in determining the informants. Purposive Sampling is a deliberate determination of informants, where there are several parties who are considered important who are directly involved in the research, [12-14]. Previously, participants had been given an explanation and signed the inform concern as a form of their willingness to become participants in this study. The data collection technique used quantitative descriptive methods which were obtained directly from respondents. Data analysis was performed using univariate analysis and presented in the form of a table that describes the amount and percentage.

\section{RESULTS}

The table below shows an overview of the new normal that has been implemented in Islamic boarding schools. Data are presented in tables and percentage form. the description of each table can be seen in the following paragraph.

TABLE I. TeACHERS Who HAVE RECEIVED COUNSELING AND TRAINING

\begin{tabular}{|c|c|c|c|c|}
\hline \multirow[b]{2}{*}{ Data } & \multicolumn{3}{|c|}{ Answers } & \multirow[b]{2}{*}{$\begin{array}{c}\text { Total }(\mathbf{N}) \\
\%\end{array}$} \\
\hline & $\begin{array}{c}\text { Not yet } \\
\text { (N) } \\
\%\end{array}$ & $\begin{array}{c}\text { Already, } \\
\text { online with } \\
\text { schools (N) } \\
\% \\
\end{array}$ & $\begin{array}{c}\begin{array}{c}\text { Already } \\
\text { from }\end{array} \\
\text { others (N) } \\
\% \\
\end{array}$ & \\
\hline $\begin{array}{l}\text { Data on teachers } \\
\text { who have } \\
\text { received } \\
\text { counseling and } \\
\text { training on } \\
\text { health protocols } \\
\text { before entering } \\
\text { dormitories }\end{array}$ & $\begin{array}{c}18 \\
(20.5 \%)\end{array}$ & $\begin{array}{c}40 \\
(45.5 \%)\end{array}$ & $\begin{array}{c}30 \\
(34.1 \%\end{array}$ & $\begin{array}{c}88 \\
(100 \%)\end{array}$ \\
\hline
\end{tabular}

TABLE II. WHERE THE STUDENTS STUDIED

\begin{tabular}{|c|c|c|c|c|}
\hline \multirow[b]{2}{*}{ Data } & \multicolumn{3}{|c|}{ Answers } & \multirow[b]{2}{*}{$\begin{array}{c}\text { Total (N) } \\
\%\end{array}$} \\
\hline & $\begin{array}{c}\text { Islamic } \\
\text { Boarding } \\
\text { School (N) } \\
\%\end{array}$ & $\begin{array}{c}\text { Dormitory } \\
\text { (N) } \\
\% \\
\end{array}$ & $\begin{array}{c}\text { Home } \\
(\mathbf{N}) \\
\%\end{array}$ & \\
\hline $\begin{array}{l}\text { Answers among } \\
\text { the teachers } \\
\text { about where the } \\
\text { students studied } \\
\text { during the } \\
\text { Covid-19 } \\
\text { pandemic }\end{array}$ & $\begin{array}{c}55 \\
(62.1 \%)\end{array}$ & $\begin{array}{c}9 \\
(10.3 \%)\end{array}$ & $\begin{array}{c}24 \\
(27.6 \%)\end{array}$ & $\begin{array}{c}88 \\
(100 \%)\end{array}$ \\
\hline
\end{tabular}

TABLE III. Procedures Before Students ENTER The Islamic BOARDING SCHOOL

\begin{tabular}{|c|c|c|c|c|c|}
\hline \multirow[b]{2}{*}{ Data } & \multicolumn{4}{|c|}{ Answers } & \multirow[b]{2}{*}{$\begin{array}{c}\text { Total } \\
\text { (N) } \\
\%\end{array}$} \\
\hline & $\begin{array}{c}\text { Rapid } \\
\text { test (N) } \\
\%\end{array}$ & $\begin{array}{c}\text { PCR } \\
(\mathbf{N}) \\
\%\end{array}$ & $\begin{array}{c}\text { Self- } \\
\text { isolation } \\
(\mathbf{N}) \\
\%\end{array}$ & Others & \\
\hline $\begin{array}{c}\text { Answers } \\
\text { from } \\
\text { teachers } \\
\text { about the } \\
\text { procedures } \\
\text { before } \\
\text { students } \\
\text { enter the } \\
\text { Islamic } \\
\text { boarding } \\
\text { school }\end{array}$ & $\begin{array}{c}43 \\
(48.9 \%)\end{array}$ & $\begin{array}{c}7 \\
(8 \%)\end{array}$ & $\begin{array}{c}29 \\
(33 \%)\end{array}$ & $\begin{array}{c}9 \\
(10.2 \%)\end{array}$ & $\begin{array}{c}88 \\
(100 \%)\end{array}$ \\
\hline
\end{tabular}

TABLE IV. TeACHERS’ PeRSPECTIVE AND EXPERIENCE RELATED TO CovID-19

\begin{tabular}{|c|c|c|c|}
\hline Data & Agree & Disagree & $\begin{array}{l}\text { Total } \\
\text { (N) \% }\end{array}$ \\
\hline $\begin{array}{l}\text { The number of } \\
\text { teachers who admit } \\
\text { to agreeing and } \\
\text { disagreeing if the } \\
\text { students or students } \\
\text { enter the boarding } \\
\text { school }\end{array}$ & $72(81.8 \%)$ & $16(18.2 \%)$ & $\begin{array}{c}88 \\
(100 \% \text { font } \\
\text { si) }\end{array}$ \\
\hline Data & $\begin{array}{c}\operatorname{Ever}(\mathbf{N}) \\
\%\end{array}$ & $\begin{array}{c}\text { Never been } \\
\text { (N) } \\
\%\end{array}$ & $\begin{array}{r}\text { Total } \\
\text { N }(\%)\end{array}$ \\
\hline $\begin{array}{l}\text { The number of } \\
\text { teachers who have } \\
\text { attended health } \\
\text { seminars on Covid- } \\
19\end{array}$ & $49(57 \%)$ & $37(43 \%)$ & $86(100 \%)$ \\
\hline Data & $\begin{array}{c}\operatorname{Ever}(\mathbf{N}) \\
\%\end{array}$ & $\begin{array}{c}\text { Never been } \\
\text { (N) } \\
\%\end{array}$ & $\begin{array}{l}\text { Total } \\
\text { (N) \% }\end{array}$ \\
\hline $\begin{array}{l}\text { Number of teachers } \\
\text { who have conducted } \\
\text { training on handling } \\
\text { infectious diseases }\end{array}$ & $37(42 \%)$ & $51(58 \%)$ & $88(100 \%)$ \\
\hline Data & $\begin{array}{c}\text { Already } \\
\text { entered (N) } \\
\% \\
\end{array}$ & $\begin{array}{c}\text { Not yet }(\mathrm{N}) \\
\%\end{array}$ & $\begin{array}{l}\text { Total } \\
\text { (N) } \%\end{array}$ \\
\hline $\begin{array}{l}\text { The answers from } \\
\text { the teachers, whether } \\
\text { the students had } \\
\text { entered the Islamic } \\
\text { boarding school or } \\
\text { not }\end{array}$ & $69(78.4 \%)$ & $19(20.2 \%)$ & $88(100 \%)$ \\
\hline
\end{tabular}


TABLE V. TEACHER's EXPECTATION TO THE SCHOOL

\begin{tabular}{|c|c|c|c|}
\hline No & $\begin{array}{l}\text { The hope of teachers to the boarding } \\
\text { school }\end{array}$ & $\mathbf{N}$ & $\%$ \\
\hline 1. & $\begin{array}{l}\text { Hopefully, there will be training and } \\
\text { seminars about Covid-19 for teachers } \\
\text { and elements of Islamic boarding } \\
\text { schools }\end{array}$ & 5 & $5.68 \%$ \\
\hline 2. & $\begin{array}{l}\text { The Islamic boarding school can start to } \\
\text { apply face-to-face learning immediately }\end{array}$ & 22 & $25 \%$ \\
\hline 3. & Pondok still organizes online learning & 1 & $1.1 \%$ \\
\hline 4. & $\begin{array}{l}\text { Strict health protocol in the cottage } \\
\text { environment }\end{array}$ & 48 & $54.60 \%$ \\
\hline 5. & $\begin{array}{l}\text { Improve support facilities to make it } \\
\text { easier for teachers to teach online or } \\
\text { offline }\end{array}$ & 9 & $10.22 \%$ \\
\hline 6. & $\begin{array}{l}\text { Islamic boarding school never give up in } \\
\text { facing this pandemic situation }\end{array}$ & 3 & $3.40 \%$ \\
\hline \multicolumn{2}{|r|}{ Total } & 88 & $100 \%$ \\
\hline
\end{tabular}

TABLE VI. TEACHER's EXPECTATION TO GOVERNMENT

\begin{tabular}{|c|c|c|c|}
\hline No & $\begin{array}{l}\text { The hope of teachers to the } \\
\text { government }\end{array}$ & $\mathbf{N}$ & $\%$ \\
\hline 1. & $\begin{array}{l}\text { Hoping for training, seminars, and } \\
\text { socialization about Covid-19 for } \\
\text { teachers and elements of Islamic } \\
\text { boarding schools }\end{array}$ & 9 & $10.22 \%$ \\
\hline 2. & $\begin{array}{l}\text { Vaccines, rapid tests, and personal } \\
\text { protective equipment are provided for } \\
\text { Islamic boarding schools }\end{array}$ & 5 & $5.68 \%$ \\
\hline 3. & $\begin{array}{l}\text { Make concrete action so that } \\
\text { participants are able to strictly improve } \\
\text { Health protocol }\end{array}$ & 13 & $14.77 \%$ \\
\hline 4. & $\begin{array}{l}\text { The government is serious about facing } \\
\text { the Covid- } 19 \text { pandemic }\end{array}$ & 45 & $51.15 \%$ \\
\hline 5. & $\begin{array}{l}\text { Supporting facilities such as } \\
\text { handwashing stations are provided to } \\
\text { prevent the spread of Covid-19 }\end{array}$ & 11 & $12.50 \%$ \\
\hline 6. & $\begin{array}{l}\text { Review the rules for studying from } \\
\text { home or online learning }\end{array}$ & 5 & $5.68 \%$ \\
\hline \multicolumn{2}{|r|}{ Total } & 88 & 100 \\
\hline
\end{tabular}

TABLE VII. TEACHER's EXPECTATION TO HEALTh CARE PROVIDER

\begin{tabular}{|c|l|c|c|}
\hline No & $\begin{array}{l}\text { The hope of teachers to the health } \\
\text { workers }\end{array}$ & $\mathbf{N}$ & $\%$ \\
\hline 1. & $\begin{array}{l}\text { Hoping that health workers provide } \\
\text { training, seminars, and socialization } \\
\text { about Covid-19 for teachers and } \\
\text { elements of Islamic boarding schools }\end{array}$ & 10 & $11.36 \%$ \\
\hline 2. & $\begin{array}{l}\text { Hopefully, the salary for health } \\
\text { workers will increase because they } \\
\text { have been fighting the pandemic }\end{array}$ & 4 & $4.54 \%$ \\
\hline 3. & $\begin{array}{l}\text { Health workers carry out regular } \\
\text { health checks at Islamic boarding } \\
\text { schools }\end{array}$ & 19 & $21.60 \%$ \\
\hline 4. & $\begin{array}{l}\text { Health workers can work more } \\
\text { optimally }\end{array}$ & $\mathbf{8 8}$ & $\mathbf{1 0 0}$ \\
\hline
\end{tabular}

There has been a change in activities, regulations when entering Islamic boarding schools and the need for health for each element in it due to the Covid-19 pandemic. Data were obtained that the number of teachers who had received counseling and training on health protocols before entering dormitories: $18(20.5 \%)$ had not, $40(45.5 \%)$ were already online with schools and $30(34.1 \%)$ were already from other parties. The number of teachers who admit to agreeing and disagreeing when students or students enter the Islamic boarding school was $72(81.8 \%)$ agree and $16(18.2 \%)$ disagree. The number of teachers who have attended health seminars about Covid-19 was 49 (57\%) have and 37 (43\%) never. The number of teachers who had conducted training on handling infectious diseases was $37(42 \%)$ are did and 51 $(58 \%)$ never.

The learning process that is usually carried out in the classroom has also changed due to the Covid-19 pandemic. The answers from the teachers about where the students studied during the Covid-19 pandemic were $55(62.1 \%)$ studied at Islamic boarding schools with implement health protocols, $9(10.3 \%)$ dormitory, and 24 (27.6\%) answered studying at home.

Islamic boarding school policies for making decisions about learning from home and application of initial screening before entering an Islamic boarding school are also being implemented. Some Islamic boarding schools adopt a policy of online learning but others have started to decide to enter with the implementation of health protocols. The answers from the teachers about whether students had entered the school or not: $69(78.4 \%)$ answered that they had already entered and $19(20.2 \%)$ answered that they had not. the teachers answered $43(48.9 \%)$ required the students to do a rapid test, 7 (8\%) required PCR and, 29 (33\%) answered that the implementation of isolation independently before entering of Islamic boarding school.

Most of the respondents considered that Islamic boarding school was not completely correct in implementing the health protocol, further, they also considered that the government was not serious in responding to the Covid-19 pandemic as well as complained that the work of health workers had not been maximal in providing services in health service facilities. It can be seen from data those $54.60 \%$ of teachers hope that the boarding school can implement strict health protocols, $51.15 \%$ of teachers hope that the government is serious about dealing with this pandemic condition and $62.50 \%$ of teachers hope that health workers can continue to work optimally in facing this pandemic condition.

\section{DISCUSSION}

The new normal has largely changed the order of lifestyle as general, the teaching and learning process at Islamic boarding schools included, $[15,16]$. Islamic boarding schools are one of the vulnerable places for being a source cluster of Covid-19 transmission if there is no control and strict health protocols implemented, [15].

Some of the health protocols that have been implemented in Islamic boarding schools so far are to reduce visitors from outside, implemented independent isolation, rapid tests, and several of students have been required to take a Swab or PCR test before entering the Islamic boarding school to ensure that these students are not at risk of becoming a new source of Covid-19 transmission, [15,17].

The majority of teachers admit that the strict application of the Health protocol has not been implemented effectively in Islamic boarding schools. The use of masks, washing hands routinely, limiting visitors from outside has not been implemented optimally. Those were related to inadequate knowledge of each element in Islamic boarding School about health protocol and the risk of Covid-19 transmission. The majority of teachers admit that when they want to strictly implement the Health protocol in the cottage environment, there are very few adequate facilities such as handwashing 
stations or others. Moreover, the number of students with the size of their classrooms does not allow for social distancing. It is necessary to think about future solutions to this situation. If there is assistance from the government for the provision of handwashing facilities in each class, it will greatly assist the lodge in dealing with this Covid-19 pandemic, $[15,16]$.

Supporting facilities and infrastructure for Islamic boarding schools that have carried out online or face-to-face learning are still insufficient. Several of the Islamic boarding schools only provide washing hands in special places, near the bathroom but other was not. In addition, adequate health equipment for students who might feel symptoms of infectious disease is also not available in the cottage environment. Equipping health facilities or equipment at the lodge such as thermometer, sphygmomanometers, oxygen, mask and first aid kits are very necessary, [15-18]. Moreover, each element in Islamic boarding schools, including teachers and students, have never been trained in the initial handling of emergency conditions. The location of the Islamic boarding school which is quite far from health facilities makes first aid is crucial. It would be more effective if the boarding school was also supported by a clinic that was managed by health workers in the future. $[15,17]$.

Although there are several Islamic boarding schools that carry out the face-to-face learning process actively, others still believe that online learning is safer. Several heads of Islamic boarding school admitted that they did not want to take risks, because if there was only one student who was affected by Covid-19, it would have an impact on the good name of the School reputation and have a big impact on the number of students who would register in the next year.

On the other hand, majority of teachers admit that online learning is ineffective. They worry that the values that are expected in the students will be lost if face-to-face learning is not carried out immediately. Online learning makes the interaction of teachers and students not dynamic, $[19,20]$. In addition, the tasks assigned to students are also irrelevant through online learning because, in Islamic boarding schools, practice is prioritized, $[15,16]$.

\section{CONCLUSION AND SugGeSTIONS}

Most of despondences expect that the government can make a decision in permitting to do face-to-face learning immediately with strict health protocol. They were hoping that health workers are also spread all information about Covid-19 and how to implement health protocol for face-to-face learning activities in Islamic boarding school. They were also expecting that the health workers can socialize all the information related to Covid-19 and the way to implement the current health protocol procedures in Islamic boarding school. As a result, all learning activities will be safe without any anxieties towards Covid-19 transmission.

\section{REFERENCES}

[1] Pangkalan Data Pondok Pesantren Kementerian Agama Republik Indonesia (Islamic Boarding School Database of the Ministry of Religion of the Republic of Indonesia) .Availableat:https://ditpdpontren.kemenag.go.id/pdpp/statistik. 2020;

[2] Ozili PK, Arun T. Spillover of COVID-19: Impact on the Global Economy. SSRN Electron J. 2020;(March).
[3] Yuniti IGAD, Sasmita N, Komara LL, Purba JH, Pandawani NP. The impact of covid-19 on community life in the province of Bali, Indonesia. Int J Psychosoc Rehabil. 2020;24(10):1918-29.

[4] Pragholapati A. New Normal "Indonesia" After Covid-19 Pandemic. 2020;2019:1-6.

[5] Habibi A. New Normal During Covid-19 (Normal Baru Pasca Covid19). JournalUinjktAcId [Internet]. 2020;4(1):197-202. Available from: http://journal.uinjkt.ac.id/index.php/adalah/article/view/15809

[6] Muhyiddin. Covid-19, New Normal, dan Perencanaan Pembangunan di Indonesia (Covid-19, New Normal and Development Planning in Indonesia). J Perenc Pembang Indones J Dev Plan. 2020;4(2):240-52.

[7] Rosidi A, Nurcahyo E. Penerapan New Normal Dalam Penanganan Covid-19 sebagai Pandemi Dalam Hukum Positif (Implementation of New Normal During Handling Covid-19 as a Pandemic in Positive Law). NASPA J. 2005;42(4):1.

[8] Nanggala A. Peran Generasi Muda Dalam Era New Normal (The Role of the Young Generation in the New Normal Era). Widya Wacana $\mathbf{J}$ Ilm [Internet]. 2020;(June). Available from: http://ejurnal.unisri.ac.id/index.php/widyawacana/article/view/3827

[9] Buheji M. Forward from "Editor in Chief": The New Normal-A New Era Full of Inspiration and Resilience after COVID-19. Int J Inspir Resil Econ [Internet]. 2020;2020(2):0-0. Available from: http://journal.sapub.org/xxx

[10] Nassaji H. Qualitative and descriptive research: Data type versus data analysis. Lang Teach Res. 2015;19(2):129-32.

[11] Lambert V a., Lambert CE. Qualitative Descriptive Research: An Acceptable Design. Pacific Rim Int $J$ Nurs Res [Internet]. 2013;16(4):255-256. Available from: http://antispam.kmutt.ac.th/index.php/PRIJNR/article/download/5805 15064

[12] Palinkas LA, Horwitz SM, Green CA, Wisdom JP, Duan N, Hoagwood K. Purposeful Sampling for qualitative data collection. Adm Policy Ment Heal [Internet]. 2015;44(12):73. Available from: https://www.ncbi.nlm.nih.gov/pmc/articles/PMC4012002/pdf/nihms538401.pdf

[13] Tongco MDC. Purposive sampling as a tool for informant selection. Ethnobotany research and applications. Ethnobot Res Appl [Internet]. 2007;5:147-58. Available from: www.ethnobotanyjournal.org/vol5/i1547-3465-05-147.pdf

[14] Etikan I. Comparison of Convenience Sampling and Purposive Sampling. Am J Theor Appl Stat. 2016;5(1):1.

[15] Syaiful FF. Pondok Pesantren Safinda IV Bangkalan di Tengah Pandemi Covid-19 (Safinda IV Islamic Boarding School Bangkalan During the Covid-19 Pandemic). Edukasi Nonform. 2020;1(2):228-35.

[16] Samsul Arifin. Dinamika Perubahan Relasi Kiai Santri Pada 'Ngaji Online' Di Masa Pagebluk Covid-19 (the Dynamics of Change in Relation Kiai Santri on 'Ngaji Online' in the Covid-19 Pandemic). J Kependud Indones. 2020;(July):75-80.

[17] Prawoto I, Rohmah SN, Sunarya FR. Peran Preventif Pemimpin Dalam Pencegahan Penyebaran COVID-19; Strategi Syaykh Al-Zaytun di Ma'had Al-Zaytun dan Kontribusinya Terhadap Masyarakat Sekitar (The Preventive Role of Leaders in Preventing the Spread of COVID19; Strategy of Shaykh Al-Zaytun in Ma'had Al-Zaytun and Its Contribution to the Surrounding Communities). SALAM J Sos dan Budaya Syar-i. 2020;7(5).

[18] Setiawan AR. Lembar Kegiatan Literasi Saintifik untuk Pembelajaran Jarak Jauh Topik Penyakit Coronavirus 2019 (Scientific Literacy Activity Sheet for Distance Learning the Topic of Coronavirus Disease 2019). Edukatif J Ilmu Pendidik. 2020;2(1):28-37.

[19] Hanum NS. Keefetifan e-learning sebagai media pembelajaran studi evaluasi model pembelajaran e-learning SMK Telkom Sandhy Putra Purwokerto (The effectiveness of e-learning as a learning medium evaluation study of the e-learning model of SMK Telkom Sandhy Putra Purwokerto). J Pendidik Vokasi. 2013;3(1):90-102.

[20] Khusniyah NL, Hakim L. Efektivitas Pembelajaran Berbasis Daring: Sebuah Bukti Pada Pembelajaran Bahasa Inggris (The Effectiveness of Online Learning: An Evidence on English Language Learning). J Tatsqif. 2019;17(1):19-33. 